and may highlight any immediate danger to the Peninsula's ecostasis. The final report will await identification of the bulk of the specimens, and this will be carried out in England. The report will form part of a socio-economic and ecological study that is being carried out by the Columbus 500 Project, which aims to involve the native inhabitants in planning the sustainable development of the region.

The team are currently fund-raising and finalizing plans for this important project. Advice or assistance of any form would be gratefully appreciated and should be addressed to the undersigned.

\section{REFERENCES}

Grubb, P.J. \& TANneR, E.V.J. (1976). The montane forests and soils of Jamaica: a reassessment. J. Arnold Arboretum, 57, pp. 313-67.

MILLIKEN, W. (1984). Interim report of The Cambridge Botanical Expedition to Venezuela, 1984. Cambridge University
Explorers \& Travellers Club Library, Cambridge, England, UK: [not available for checking].

Steyermark, J. \& Agostini, G. (1966). Exploracion Botanica del Cerro Patao y Zonas adyacentes a Puerto Hierro, en La Peninsula de Paria, estado Sucre. Acta Botanica Venezuela, 1(2), pp. 7-80.

Sugden, A.M. (1982). The vegetation of the Serrania De Macuira, Guajira, Colombia: a contrast of arid lowlands and an isolated cloud forest. J. Arnold Arboretum, 63, pp. 1-30.

SUGDEN, A.M. (1986). The montane vegetation and flora of Margarita Island, Venezuela. J. Arnold Arboretum, 67, pp. 187-232.

\title{
Air Pollution and Forest Damage in Europe: Still Critical but Some Improvements
}

Air pollution continues to take a heavy toll in Europe, according to a survey of forest health in 26 states coordinated by the United Nations Economic Commission for Europe (ECE). Compared with previous years, several countries reported a further increase in forest damage during 1989 - especially in Eastern Europe - while in other countries the degree of defoliation appears to have stabilized or actually decreased.

The ECE forest damage survey - fourth in a series of annual reports undertaken since 1986 with the assistance of the United Nations Environment Programme - was carried out by an international programme task-force led by the Federal Republic of Germany, in the context of the 'Convention on Long-range Transboundary Air

TABLE I

1989 ECE Survey: Coniferous Forests - All Ages - Defoliation by Classes.**

\begin{tabular}{|c|c|c|c|c|c|c|}
\hline $\begin{array}{l}\text { Participating countries } \\
\text { etc. }\end{array}$ & $\begin{array}{c}\text { Coniferous } \\
\text { forest } \\
(1,000 \mathrm{ha})\end{array}$ & $\begin{array}{c}0 \\
\text { none } \\
(\%)\end{array}$ & $\begin{array}{c}1 \\
\text { slight } \\
(\%)\end{array}$ & $\begin{array}{c}2 \\
\text { moderate } \\
(\%)\end{array}$ & $\begin{array}{c}3+4 \\
\text { severe } \\
(\%)\end{array}$ & $\begin{array}{c}2+3+4 \\
(\%)\end{array}$ \\
\hline Austria & 2,518 & 76.0 & 19.9 & 3.3 & 0.8 & 4.1 \\
\hline Belgium (Flanders) & 54 & 35.9 & 49.1 & 13.6 & 1.4 & 15.0 \\
\hline Belgium (Wallonia) & 248 & 47.6 & 28.5 & 20.0 & 3.9 & 23.9 \\
\hline Bulgaria & 1,172 & 22.0 & 45.1 & 30.6 & 2.3 & 32.9 \\
\hline Byelorussian SSR* & 4,760 & 12.0 & 12.0 & 68.0 & 8.0 & 76.0 \\
\hline Czech \& Slovak Fed. Rep. & 2,891 & 27.0 & 41.0 & 26.0 & 6.0 & 32.0 \\
\hline Denmark & 308 & 55.0 & 21.0 & 21.0 & 3.0 & 24.0 \\
\hline Finland & 18,484 & 59.3 & 22.0 & 16.4 & 2.3 & 18.7 \\
\hline France & 4,840 & 75.4 & 17.4 & 6.7 & 0.5 & 7.2 \\
\hline Germany (East) & 2,003 & 42.8 & 39.7 & 14.8 & 2.7 & 17.5 \\
\hline Germany (West) & 5,078 & 51.5 & 35.3 & 12.3 & 0.9 & 13.2 \\
\hline Greece & 954 & 57.8 & 35.5 & 5.9 & 0.8 & 6.7 \\
\hline Hungary & 1,405 & 64.3 & 22.4 & 11.7 & 1.6 & 13.3 \\
\hline Ireland & 334 & 47.2 & 39.6 & 12.6 & 0.6 & 13.2 \\
\hline Italy & 1,735 & 77.0 & 13.8 & 7.6 & 1.6 & 9.2 \\
\hline Italy (Bolzano) & 292 & 81.6 & 14.1 & 3.8 & 0.5 & 4.3 \\
\hline Luxembourg & 31 & 74.9 & 15.6 & 7.7 & 1.8 & 9.5 \\
\hline Netherlands & 208 & 53.2 & 29.1 & 15.5 & 2.2 & 17.7 \\
\hline Norway & 5,925 & 57.0 & 28.2 & 12.5 & 2.3 & 14.8 \\
\hline Poland & 6,895 & 17.8 & 47.7 & 32.8 & 1.7 & 34.5 \\
\hline Portugal & 1,315 & 83.5 & 6.7 & 4.9 & 4.9 & 9.8 \\
\hline Spain & 5,637 & 78.7 & 17.8 & 3.1 & 0.4 & 3.5 \\
\hline Sweden & 19,400 & 51.9 & 35.2 & 11.3 & 1.6 & 12.9 \\
\hline Switzerland & 777 & 53.0 & 33.0 & 11.0 & 3.0 & 14.0 \\
\hline Ukrainian SSR* & 4,159 & 83.5 & 15.1 & 1.4 & 0.0 & 1.4 \\
\hline USSR (Estonia) & 1,153 & 38.8 & 32.7 & 27.8 & 0.7 & 28.5 \\
\hline USSR (Kaliningrad) & 123 & 11.0 & 46.0 & 41.0 & 2.0 & 43.0 \\
\hline USSR (Lithuania) & 1,008 & 32.0 & 44.0 & 22.0 & 2.0 & 24.0 \\
\hline United Kingdom & 1,550 & 36.0 & 30.0 & 25.0 & 9.0 & 34.0 \\
\hline Yugoslavia (Slovenia) & 1,210 & 33.6 & 27.3 & 22.9 & 16.3 & 39.1 \\
\hline
\end{tabular}

* Selective regional surveys.

** Defoliation classes (percentage of needles lost): $0=<10 \% ; 1=10-25 \% ; 2=25-60 \% ; 3=>60 \% ; 4=$ dead trees. 
TABLE II

1989 ECE Survey: Broad-leafed Forests - All Ages - Defoliation by Classes.**

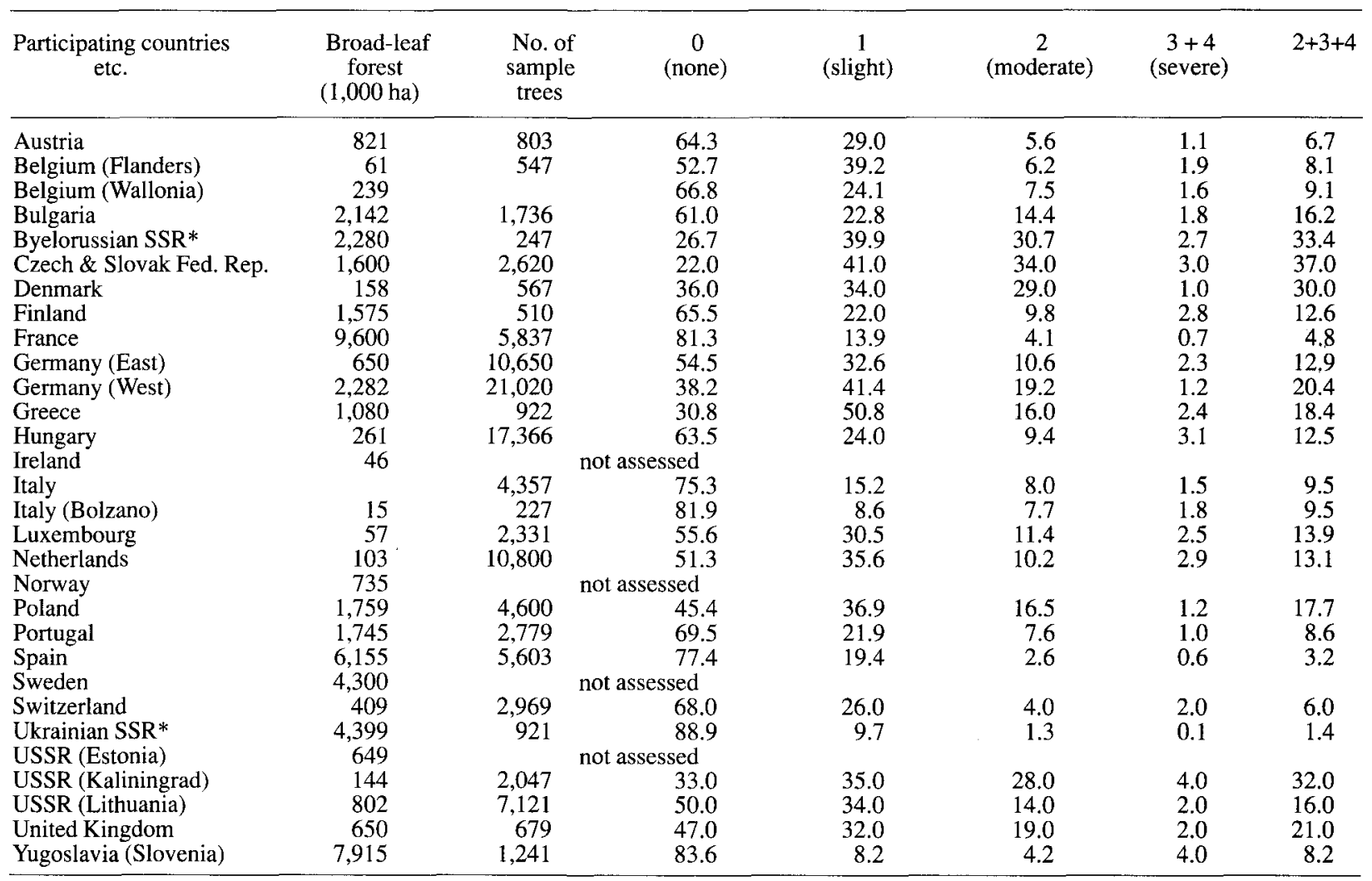

* Selective regional surveys.

** Defoliation classes (percentage of leaves lost): $0=<10 \% ; 1=10-25 \% ; 2=25-60 \% ; 3=>60 \% ; 4=$ dead trees.

Pollution'. The results of the survey were presented to the Convention's Working Group on Effects, meeting in Geneva, Switzerland, on 27-29 August 1990.

The 1989 survey covered 116 million hectares, comprising two-thirds of the entire forest area in Europe. For the first time, data on forest damage in the western parts of the USSR (Ukrainian SSR, Byelorussian SSR, and the Kaliningrad region) are included, in addition to the Estonian and Lithuanian SSR which had already reported in previous years.

The survey shows the rate of defoliation (loss of needles and leaves in different species and age-groups of coniferous (Table I) and broad-leafed (Table II) forests, respectively. Spruce (Picea), fir (Abies), and oak (Quercus), are currently the genera most heavily affected. In the age-group of trees of more than 60 years, moderate to severe defoliation affects more than $15 \%$ of all spruce trees in 16 countries, of all fir trees in seven countries, and of all oaks in 15 countries. This implies that, in more than half of the participating states, older trees of these species are in a precarious state of health.

In most countries, damage to spruce remained stable or decreased slightly in 1989, although a notable deterioration was recorded in Czechoslovakia, Poland, and the Lithuanian SSR. While the condition of pine (Pinus spp., mostly $P$. sylvestris remained generally unchanged, Bulgaria, the Lithuanian SSR, Hungary, Portugal, The Netherlands, the German Democratic Republic, and Switzerland, all showed a negative trend for older trees. The situation of Silver Fir (Picea alba) continues to be critical. Defoliation in oaks became significantly more serious, with the exception of recoveries reported from Greece, The Netherlands, and the United Kingdom. Common Beech (Fagus sylvatica) improved slightly in most countries, which in some cases is attributed to recovery from earlier insect attacks.

The Programme Task Force emphasized that it is extremely difficult to draw comparisons between the data collected by different countries. The condition of European forests depends on species composition, age structure, site and climatic factors, and traditional forms of damage. The relative importance of these varies between regions, and despite the high level of harmonization in assessment methods that has now been achieved between the participating countries, important differences still remain. Intercalibration will therefore remain a continuous task of the programme. For this purpose, international training courses in forest damage assessment were held in July 1990 in Prachatice (Czechoslovakia) and in Volterra (Italy).

Preparations for the next ECE survey are now under way in all participating countries, together with a major joint assessment of cause-effect relationships between air pollution and forest damage. In submitting the results of its 1989 survey to the Working Group on Effects, the Programme Task Force stated its concern over the continuing decline of forests and continuing acidification of forest soils in Europe, and stressed the need for further action to reduce air pollution.

UNITED NATIONS ECONOMIC COMMISSION FOR EUROPE Palais des Nations

1211 Geneva

Switzerland. 